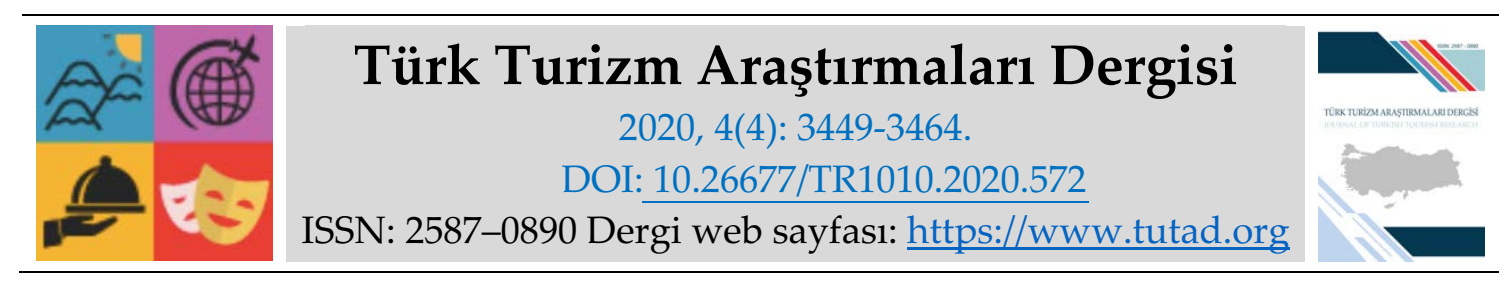

ARASTIRMA MAKALESI

\title{
Galata Kulesi ve Kız Kulesi'nin Söylence Turizmi Kapsamında İncelenmesi
}

Prof. Dr. İsmail KIZILIRMAK, İstanbul Üniversitesi, İktisat Fakültesi, İstanbul, e-posta: ikizilirmak@yahoo.com

ORCID: https://orcid.org/0000-0001-9141-6420

Öğr. Gör. Evren GÜMÜŞ, T.C. İstanbul Şişli Meslek Yüksekokulu, İstanbul, e-posta: evren.gumus@sisli.edu.tr

ORCID: https://orcid.org/0000-0002-2497-4630

Öz

Tarih boyunca farklı kültürler arasında anlatılagelen efsane ve söylenceler, günümüz turistinin temel seyahat motivasyonlarından biri olmaya devam etmektedir. Bu bağlamda İstanbul destinasyonunun iki simge turistik mekanlarl; Galata Kulesi ve Kız Kulesi, efsane ve söylence turizmi kapsamında yerli turistlerin perspektifinden değerlendirilmektedir. Efsane ve söylencelerin bu turistik mekanlar üzerinde bir çekicilik oluşturup oluşturmadığ araştırılmaktadır. Araştırmada yarı yapılandırılmış görüşme yöntemi uygulanarak, 24 katılımcıyla yüz yüze görüşme yapılmıştır. Araştırmanın evrenini Galata Kulesi ve Kız Kulesi'ni ziyaret eden yerli turistler oluşturmaktadır. Galata Kulesi ve Kız Kulesi İstanbul'un iki farklı yakasında konuşlanmıştır. Mekan dağılımındaki farklı konumlar ve turist sayısının çokluğundan dolayı bu araştırmada nitel araştırmalarda kullanılan amaçlı örnekleme yönteminden yararlanılmıştır. Katılımcıların Galata Kulesi ve Kız Kulesi ziyaretlerinde efsane ve söylencelerin etkili olduğu tespit edilmiştir.

Anahtar Kelimeler: Efsane, Söylence, Galata Kulesi, Kız Kulesi, Çekicilik.

Makale Gönderme Tarihi: 04.05.2020

Makale Kabul Tarihi: 02.10 .2020

\section{Önerilen Atıf:}

Kızılırmak, İ. ve Gümüş, E. (2020). Galata Kulesi ve Kız Kulesi'nin Söylence Turizmi Kapsamında İncelenmesi, Türk Turizm Araştırmaları Dergisi, 4(4): 3449-3464.

(c) 2020 Türk Turizm Araştırmaları Dergisi. 


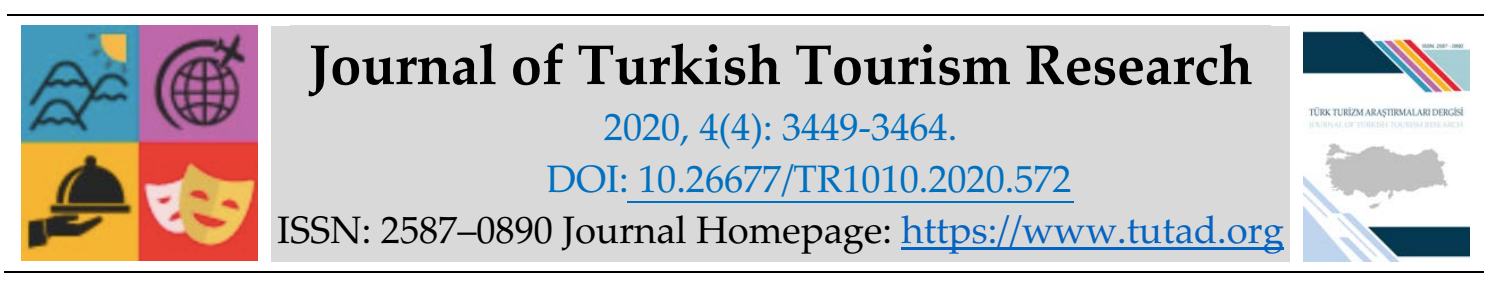

\title{
RESEARCH PAPER
}

\section{Comparison of Galata Tower and Kiz Tower in the Context of Myth Tourism}

Prof. Dr. İsmail KIZILIRMAK, İstanbul University, Faculty of Economics, İstanbul, e-mail: ikizilirmak@yahoo.com

ORCID: https://orcid.org/0000-0001-9141-6420

Lecturer Evren GÜMÜŞ, İstanbul Şişli Vocational School, İstanbul, e-mail: evren.gumus@sisli.edu.tr

ORCID: https://orcid.org/0000-0002-2497-4630

\begin{abstract}
The legends and myths that have been told between different cultures throughout history continue to be one of the main travel motivations of today's tourists. In this context, two landmarks of Istanbul destination are; Galata Tower and Kiz Tower are evaluated from the perspective of domestic tourists within the scope of legend and myhth tourism. It is explored whether legends and myths create a charm on these attractions. In the research, semi-structured interview method was applied and face to face interviews were made with 24 the participants. Domestic tourists visiting Galata Tower and Kız Tower constitute the universe of the research. The purposeful sampling method used in qualitative research was used in this research because of the different locations in the distribution of space and the large number of tourists. It was determined that legends and myths were determinant in the participants' visits to Galata Tower and Kiz Tower.
\end{abstract}

Keywords: Legend, Myhth, Galata Tower, Kız Tower, Attraction.

Received: 04.05.2020

Accepted: 02.10.2020

\section{Suggested Citation:}

Kızllırmak, İ. and Gümüss, E. (2020). Comparison of Galata Tower and Kız Tower in the Context of Myth Tourism, Journal of Turkish Tourism Research, 4(4): 3449-3464.

(C) 2020 Türk Turizm Araştırmaları Dergisi. 


\section{Gíriş}

Somut olmayan kültürel miras, toplumların yaşama biçimleri etrafında meydana gelmiş farklı kültürel değerlerdir. Kültürel mirasın bu yönü aktarılarak ve yaşanarak korunabilmektedir. Turizm endüstrisinde kültürün her biçimi turistik bir ürün niteliğindedir (Ar ve Uğuz, 2015: 1406). Turistlerin uzak mesafelere seyahat etmesinin en önemli nedenlerinden biri; farklı kültürleri ve yerleri merak edip tanıma isteğidir. Tarih boyunca, Doğu ve Batı arasındaki ticari, askeri, dini, ekonomik ve merak amaçlı seyahatlerde anlatılan efsane ve söylenceler, günümüzdeki turistin temel seyahat içgüdülerinden biri olmaya devam etmektedir (Yenipınar, 2018: 325). Çünkü bireylerin tarihi akış düzleminde elde ettikleri bilgiler, toplumun "ortak bilgisi"ni oluşturur. Bilgilerin korunarak, geliştirilerek ve kalıp haline getirilerek kuşaklar arası aktarılmasıyla toplumun ortak hafızası şekillenir (Sever, 2008: 61). Oluşan bu ortak kültür turizmin gizemli yanına işaret eder. Turistler içgüdüyle ziyaretlerde bulunarak turistik mekanları deneyimlemek istemektedirler.

Turistlerin zihninden silinemeyecek kadar güzel ve unutulmaz bir deneyimin kurgulanması için bir ana fikrin oluşturulması gerekmektedir. Deneyimin temel fikrinin oluşturulmasında dikkat edilmesi gereken esas nokta, ana fikrin diğerlerinden özgün olmasıdır. Turistlerin bulundukları turistik mekanda nasıl bir deneyim yaşayacağını kısa sürede anlaması ya da gideceği yerin ona nasıl bir deneyim yaşatacağının farkında olması esastır (Pine ve Gilmore, 1998). İstanbul destinasyonun sahip olduğu; Byzas'ın Kurduğu Şehir, Süleyman Peygamber'in İstanbul'u kurması, Kıztaşı, Fetih Esnasında Ayasofya'ya İnecek Melek, Fatih Sultan Mehmed ve Hızır, Sultanahmet Camii'nin Altın Minareleri, Eyüp Sultan, Kıyamete Kadar Ayakta Kalacak Cami, Topkapı Sarayı'ndaki Kutsal Emanetler gibi efsane ve söylenceler, turistin yaşayacağı deneyimin ortaya çıkması aşamasında kullanılacak önemli somut olmayan kültürel miraslardır.

Bu çalışmada İstanbul destinasyonu akla geldiğinde, zihinlerde hemen beliriveren Galata Kulesi ve Kız Kulesi turistik mekanları; efsane ve söylence turizmi çerçevesinde incelenmektedir. İki sembol turistik mekânın; turistik bir çekicilik oluşturma noktasında efsane ve söylencelerin etkisinin olup olmadığı değerlendirilmektedir. Aynı zamanda bu iki mekan arasında "efsaneler" üzerinden bir bağ olup olmadığı araştırılmaktadır.

\section{Efsane ve Söylencelerin Destinasyon Deneyimine Katkısı}

Efsane, batı dillerine aynı Latince kökten "legendus" sözcüğünden gelmiştir. Efsane, Farsça bir sözcük olup "efsane" diye kullanılmaktadır. Türkçede efsane karşılığı olarak "söylence" önerilmiştir (Yavuz, 1998: 91). Söylenceler (Mitoloji); insanlığın sahip olduğu mitleri ele alıp sistematik olarak inceleyen bilim dalıdır (Gündüz, 1998: 265).

Efsane hakkında ilk tanım Grimm Kardeşler'e aittir ki şöyledir: "Gerçek veya hayalî belirli şahıs, olay veya yer hakkında anlatılan bir hikâyedir." Bu tanımda öne çıkan ve efsaneyi kendine özgü tür kılan şey, ondaki "gerçeklik" unsurudur. Efsanelerde bahsi geçen kişi, yer ve olaylar gerçektir (Sakaoğlu, 1980: 4). Türk Dil Kurumu sözlüğünde efsane; “eski çağlardan beri söylenegelen, olağanüstü varlıkları, olayları konu edinen hayali hikaye, söylence" diye tanımlanmıştır (TDK, 2020). Diğer bir tanımda ise; "kişi yer ve olayları konu alan, inandırıcılık özelliğine sahip çoğu zaman olağanüstülüklere yer veren, belirli bir üsluba ve şekle bağlı olmayan, kaynaklarını genellikle geçmişin derinliklerinden alan kısa, yalın, ağızdan ağıza aktarılan ortak (anonim) halk anlatılarıdır (Yavuz, 1998: 91).

$\mathrm{Bu}$ tanımlardan hareketle efsane konusunda şu saptamalar yapılabilir: Efsaneler, dilden dile anlatılagelmiş çok eski hikayelerdir ve anonim halk edebiyatı ürünleridir. Efsanelerin konuları bir kişiye, bir olaya ya da bir yere atfedilir. Efsanelerde anlatılanların bir nebze de olsa gerçekçilik 
özelliği vardır. Efsanelerde sıklıkla olağanüstülük ağır basarken, efsaneleri inandırıcı kılan en önemli unsur, din ve inançla ilgili algılardır (Sakaoğlu, 1980; Yavuz, 1998).

Efsane ve söylenceler, somut olmayan kültürel miras niteliği taşıdığı için, somut kültürel mirasların neden, nasıl, niçin, hangi duygu ve düşüncelerle yapıldıklarını anlaşılır kılarak turistlerin tarihi dönemlerdeki yaşamları anlamalarına yardımcı olur. Türkiye, turizm potansiyeline sahip çok sayıda kadim kent, bölge ve beldeye sahip bir ülkedir. Tarihi süreçlerden günümüze kadar yerleşim yeri olma özelliğini koruyan kentlerin birden fazla kuruluş öyküsü, tarihi ismi, bir o kadar yaşanmışlıkları anlatan efsane ve söylencesi vardır. Efsane ve söylenceler turizmde az sayıda destinasyonun sahip olduğu zengin öz değerlerden biri olup, turistleri fiziksel, duygusal, zihinsel ve ruhsal olarak etkileyen, kişisel deneyim edinmelerine ve hatıralarında iz bırakacak bir deneyim yaşamalarına katkı sunan görünmez turistik ürünlerdir (Yenipınar, 2018: 325). Aynı zamanda efsaneler yardımıyla geçmiş ile gelecek arasında bir bağlantı kurulabilmektedir. Ülkemizdeki tarihi birçok mekana ait sayısız efsaneler mevcuttur. Bu efsaneler yardımıyla geçmişte yaşamış toplumlara ait birçok bilgiye ulaşılabilir (Aktaş ve Batman, 2010: 374).

Destinasyon deneyiminin etkili hale getirilebilmesi için tanıtım koordinasyonunun bütüncül bir yaklaşımla ele alınması zorunluluğu vardır (Ersun ve Arslan, 2011: 240). Somut olmayan kültürel mirasında bu kapsamda değerlendirilmesi gerekmektedir. Efsane ve söylenceler; turistte ilgi uyandırdığı kadar, yerel halkın kültürel zenginliklerini öğrenip tecrübe etmesine ve bunu yaparken de zevk almasına katkı sağlamaktadır (Illban, 2007).

Bir turistik ürünün pazarlamasında söylencesi olan destinasyonların daha kolay pazarlanabildiği görülmektedir. Son yıllardaki turist profili somut harika mimari eserler kadar, anılan şehirlerin somut olmayan kültürel mirası ve o bölgede yaşayan yerel halkın yaşamına dair detayları merak etmektedir. Örneğin; "Nasıl bir evde yaşıyor, neleri seviyor, nelere üzülüyor, sanatçları kimlerdir, gösterişli tapınaklar hangi tanrılar için ve kimler tarafından yapılmış, dini törenleri nasıldır, neleri kutsal görmektedir?" gibi sorularla ilgi duyduğu yeri kendisi görüp, anlayıp tecrübe ederek öğrenmek istemektedir. Günümüzde ülke tanıtımları yerine, bölgeleri ve bölgelerin belli şehirlerinin turistik ürün noktalarına dikkat çekilerek bölgesel ve kentsel turistik tanıtım ve pazarlama faaliyetleri yapılmaktadır (Yenipınar, 2018: 330). Post modern turist profilinin artık fonksiyonel özellikler yerine, ürünün duygusal ve sembolik değerlerine daha çok önem verdiği görülmektedir. Turist duygusal anlamda tatmin olmak istemekte ve turistik ürünün kendisine unutulmaz deneyimler yaşatmasını istemektedir (Kara ve Çiçek, 2015: 178). Bu kapsamda turistik ürünün çekiciliğini artırabilmek adına konunun hikayeleştirilmesi önemlidir. Hikaye anlatımı, geçmişten günümüze var olan efsaneleri ağızdan ağıza toplum içerisinde yayılmasını sağlayan bir anlatı tarzı olarak görülmektedir (Dönmez ve Güler, 2016: 156). Uygur vd. (2017), yaptıkları çalışmada olayı biraz daha farklı bir boyutla değerlendirmiştir. Hikayelerin insanları büyük ölçüde ikna ederek etkileyebilme gücüne sahip olması ve pazarlama iletişim sürecinin önemli bir unsuru olmalarını sağladığı tespit edilmiştir. Tüketicilere bilindik turizm anlayışı dışında, seyahat dönüşü anlatabilecekleri farklı ve eğlenceli bir deneyim sunulmasının önemli bir pazarlama trendi haline geldiği vurgulanmıştır.

\section{Efsane ve Söylence Turizmi ile İlgili Yapılmış Çalışmalar}

Literatürde efsane ve söylence turizmi ile ilgili yapılmış çeşitli çalışmalara rastlamak mümkündür (Şahin, 2009; Aktaş ve Batman, 2010; Bryon, 2012; Türker ve Çelik, 2012; Özünel, 2013; McKercher ve Prideaux, 2014; Jeannotte, 2015; Coşkun, 2017; Gül, 2017; Bassano, Barile, Piciocchi, Spohrer, Iandolo ve Fisk, 2019; Grimwood, Stinson ve King, 2019; Sezer, 2019). Şahin (2009), Dalyan ve Köyceğiz çevresinde gelenek ve turizm ilişkisi çerçevesinde efsanelerin turizm 
faaliyetlerinde kullanımını değerlendirmiştir. Dalyan ve Köyceğiz'i ziyarete gelen yerli ve yabancı turistlere Dalyan' daki kanallarla ve Köyceğiz' deki kaplıca ile ilgili efsaneler anlatılmıştır. Ayrıca bu efsanelerin, bölgenin cazibe merkezi olmasına katkı yaptıkları gibi, geleneğin pazarlanabilme kabiliyetini göstermesi açısından da kayda değer bir unsur olduğu vurgulanmıştır. Aktaş ve Batman (2010) 'ın yaptığı çalışmada ise efsanelerin turist rehberleri tarafından tur programlarında kullanıldığı, turistik çekicilik üzerinde etkileri olduğu, turistik tanıtımda bir pazarlama vasıtası olarak kullanılabileceği ve efsanelerden istifade ederek yapılacak olan tanıtımlarda bazı bölgeler için bir sembol olabileceği görülmüştür. Bryon (2012), nitel bir çalışma kapsamında, turist rehberlerinin söylenceleri kullanarak niş turizm pazarı üzerine odaklandıkları ortaya konmuştur. Türker ve Çelik (2012), somut olmayan kültürel miras unsurlarının turistik ürün olarak mevcut kullanımı üzerinde durmuş ve alternatif ürün geliştirme örnekleri verebilme konusunu incelemişlerdir. Özünel (2013), bütünsel koruma ve sürdürülebilirlik yaklaşımlarının somut olmayan kültürel mirasla birlikte düşünülebilecek yönlerine odaklanmıştır. Bu bağlamda makalede yeni sözleşmelerden birinde tanımlanmış olan somut olmayan kültürel mirasın uluslararası toplum tarafından algılanış biçimi ve bu algının yönetilme stratejileri tartışılmıştır. McKercher ve Prideaux (2014), anket tekniği kullanarak yaptığı çalışmada; turizm kültürünün oluşmasında mitlerin oynağı roller incelenmiştir. Bazı efsanelerin turistik destinasyonun imajına zarar verebileceği sonucuna ulaşılmıştır. Jeannotte (2015), somut olmayan kültürel varlıkların aktarılmasında yerel halkın öyküleri anlatma ve bunları kalııı hale getirme noktasındaki çabaları incelenmiştir. Coşkun (2017), uzun süredir iskan edilen bölgelerde etnik ve dini çeşitliliğin doğal bir sonucu olarak söylence sayısının fazlalığını tespit etmiştir. Bu bağlamda Van şehrinin bu duruma kayda değer bir örnek olduğu ifade edilmiştir. Bölgede Urartu döneminden günümüze kadar sürekli ve yoğun yerleşime sahne olan farklı efsaneler mevcuttur. Mitolojik öğeler barındıran bu söylencelere insanların merak duydukları belirtilmiştir. Gül (2017), Amasya'ya gelen turistlerin Amasya'yı tercih nedenleri ve güdülenmelerinde Ferhat ile Şirin, Serçoban, İğneci Baba ve Güzelce Kız (Aynalı Mağara Efsanesi) gibi efsane ve mitlerin etkisinin olduğunu ortaya koymuştur. Ancak çalışma ile Amasya'nın turizm tanıtımında kullanılan kitap ve broşürlerde Amasya ile ilgili mit ve efsanelerin sık kullanılmadığı görülmüştür. Bassano vd. (2019), turistik destinasyonlar hakkındaki efsanelerin, bölgelerin turistik çekiciliğini arttırmada rekabetsel bir araç olarak kullanıldığı sonucuna ulaşmışlardır. Grimwood vd. (2019), yapılan örnek olay incelemesiyle, Kanada'daki Thelon Nehri havzasıyla ilgili anlatılan yerel efsanenin turistler arasında yüksek bir çekiciliğe sahip olduğunu belirtilmişlerdir. Özellikle turistlerin efsaneyi yerel halkın ağzından dinleme isteğinin ön planda olduğu görülmüştür. Sezer (2019), Giresun Adası'nın bağlantılı olduğu mitolojik öykülerin ve efsanelerin, adanın turizm potansiyeline olan etkilerinin ortaya çıarılmasını hedeflemiştir. Giresun Adası'nın başta mitolojik öyküleri ve efsaneleri olmak üzere, tarihi kalıntıları ve doğal özellikleriyle değerlendirilebilecek düzeyde turizm potansiyeline sahip olduğu, ankete katılanların da adanın turizme kazandırılmasını destekledikleri anlaşılmaktadır.

$\mathrm{Bu}$ alanda yapılmış çalışmalar değerlendirildiğinde, Galata Kulesi ve Kız Kulesi'ni, yerli turistlerin perspektifinden "efsaneler" bağlamında ele alan bir çalışmaya rastlanmamaktadır. Bu nedenle yapılan çalışmanın konu ile ilgili literatüre katkı sağlayacağı düşünülmektedir.

\section{Galata Kulesi ve Kız Kulesi}

Galata Kulesi İstanbul'un en eski yapılarından biri olarak dikkat çekmektedir. Kule sayısız depreme, yangına direnmiş ve yıkılmayarak ayakta kalmıştır (Acarer, 2015: 287). Bu yapıyı, 1348 yılında Cenevizliler İstanbul siluetine armağan etmiştir. Haliç tarafından bakıldığında 62 metrelik boyu ve 12 katıyla tarihi binaların arasından fark edilen Galata Kulesi, İstanbul'u 
seyredebileceğiniz en özel mekanlardan biridir. Bizans kaynaklarında "Büyük Burç", Cenova kaynaklarında ise "İsa Kulesi" isimleriyle anılan kule, Cenevizlilerin döneminde gözetleme amacıyla kullanılmıştır. 1509 yılında İstanbul'u sarsan ve "Küçük Kıyamet" adı verilen depremde zarar gören kule, II. Bayezid'in buyruğuyla onarılmıştır. Günümüzde ise turizme hizmet vermektedir. Seyir terası ile yıl boyu ilgi gören kule, 360 derecelik panoramik manzarası ve gökyüzünü adeta yırtan sağlam gövdesiyle, büyülü mizacını devam ettirmektedir. Kuleye çıkşsta ilk 7 kat asansör ile çıkılıp diğer 2 kata merdivenle devam edilmektedir. İnişte ise tüm katları merdivenle inmeniz gerekmektedir. Galata Kulesi'nin 9. katı ise gündüzleri kafeterya akşam saatlerinde ise restoran olarak hizmet vermektedir. Bu kafeterya ve restoran İstanbul Büyükşehir Belediyesi (IBB) kuruluşu Beltur tarafından işletilmektedir. Bu kuleye haftanın her günü sabah saat 09.00 ile akşam 19.00 arasında ziyaret imkanı bulunmaktadır (Uslu, 2018: 185).

Efsane ve söylence kapsamında ele alındığında ise Galata Kulesi ile ilgili olarak en eski ve en dikkat çekici olan efsane; "çiftlerin Galata Kulesi'ne ilk kez birlikte çıkarlarsa mutlaka evlenecekleri" ile ilgili olan efsanedir. Bu efsanenin kökeni Romalılara dayanmaktadır. Romalılar'a göre: Şayet bir kadın ve erkek, Galata Kulesi'ne ilk kez beraber çıkarlarsa, onlar kesin bir şekilde evlenirler. Ancak eşlerden biri daha önceki seferlerde kuleye çıktıysa (başka biriyle ya da yalnız başına çıkması fark etmez), bu gizem kaybolurmuş. Ayrıca eğer kuleye beraber çıkacak çiftin kaderinde kavuşamamak varsa karşılarına mutlaka bir engel çıkarmış. Çünkü Galata Kulesi, bir ömür beraber yaşamayacak çiftleri kabul etmezmiş (www.tarihiistanbul.com).

Diğer bir efsaneye göre ise Galata Kulesi ve Kız Kulesi'nin birbirlerine aşık olduğu söylenir. Ancak aradaki çetin boğaz sebebiyle bir araya gelmeleri de olanaksızdır. Günler geçtikçe birbirlerine olan hasretleri artmaktadır. Derken günün birinde, Hezarfen Ahmet Çelebi Avrupa'dan Anadolu yakasına uçmak üzere kuleye tırmanır. Galata Kulesi'nin baskılarına direnemeyip, kulenin yüzyıllardır sakladığı mektupları da yanına alarak uçar ve onları Salacak Sahili'ne yaklaşttğı sırada Kız Kulesi'ne bırakır. Rüzgarın da etkisiyle etrafa dağılan mektuplar dalgaların da etkisiyle Kız Kulesi'ne ulaşır. Sevgisinin karşılığı olduğunu anlayan Kız Kulesi, mektuplardan sonra gösterişli bir şekle dönüşür. Bu durumun ortaya çıkmasıyla Galata Kulesi de beğenisinin tek yönlü olmadığını anlar. İkilinin karşılıklı olarak taşıdığı bu hisler, onların zamana karşı meydan okumalarını sağlar. Bu efsanenin daha çok masalımsı bir hikayeyi anlattığı görülmektedir (www.tarihiistanbul.com).

Halk ve Anadolu edebiyatının masal, efsane ve deyişlerinden çok etkilenen Bedri Rahmi Eyüboğlu'nun şiirleri de bu etkinin altındadır (Bilgi World, 2019). Şair, Galata ve Kız Kuleleri'nin birbirlerine olan aşkına da "İstanbul Destanı" adlı şiirinde yer vermiştir (Tonguç ve Tutuk, 2019: 154-156):

“İstanbul deyince aklıma kuleler gelir. Ne zaman birinin resmini yapsam, öteki kıskanır. Ama şu Kız Kulesi'nin aklı olsa Galata Kulesi'ne varır. Bir sürü çocukları olur".

Üsküdar'ın Salacak Sahili'ndeki Kız Kulesi, 12. yüzyılda İmparator Manuel Komnenos tarafından yaptırılmıştır. Önceleri bir mezar yapısı olan kayalık sonrasında deniz feneri ve gümrük binası olarak ihtiyaca cevap vermiştir. Osmanlı döneminde boğazdan geçen gemilerden alınan vergiler bu adada tahsil edilmiştir. Adanın bazı zamanlarda salgın hastalıklara tedbir olarak karantina istasyonu olarak kullanıldığı da olmuştur (Demirdurak, 2013: 54). 1725-1726 yıllarında Nevşehirli Damat İbrahim Paşa tarafından bugüne ulaşan kule yaptırılmıştır. 1857 yılında Fenerler İdaresi'ne tahsis edilmiştir. 1944 yılında onarılan kule, 1960'lı yıllarda Deniz Kuvvetleri Komutanlığı tarafından kullanılmıştır. 1982 yılında da Türkiye Denizcilik İşletmeleri'ne tahsis edilen yapı, 2000'li yıllarda onarılarak restoran, kafeterya ve hediyelik eşya satan turistik bir yer haline gelmiştir (Demircan, 2011: 258). 
Kız Kulesi ile ilgili en çok bilinen efsane ise "Sepetteki Zehirli Yılan" efsanesidir. Efsaneye göre; vaktiyle bilinmeyen bir kralın, falcının bir yılan tarafından sokularak öleceğini söylediği kızını korumak için, onu bu adaya saklamış olduğu anlatılır. Ancak kıza ulaştırılan bir incir sepetinin içinden çıkan yılan, kızı sokar ve öldürür (Hürel, 2015: 506).

Bir diğer efsaneye göre ise Kız Kulesi'ndeki güvercinlerle ilgilenen görevli Hero, Aşk Tanrıçası Afrodit'in rahibesidir. Rahibe olduğu için de dış dünyayla irtibat kurması ve aşık olması yasaktır. Yalnızca tabiatın yeniden canlandığı zamanlarda karada bulunan tapınağı ziyaret etmesine müsaade edilirdi. Hero, bu özel günlerden birinde çiçeklerle bezeli olan kıyafetleriyle tören yerine giderken kralın oğlu Leandros ile karşı karşıya gelir. Gençler birdenbire hissettikleri aşk duygusuna mani olamazlar. Ardından boğazın amansız sularını sevdiğinin yaktığı ateşe doğru hızlı bir şekilde yüzerek aşmayı başaran Leandros ile Hero buluşmaya başlarlar. Lakin gecenin birinde çıan fırtına meşaleyi etkisiz hale getirir ve dalgalar Leandros'u çok uzaklara fırlatır. Sabahında sevgilisinin suda dolaşan cesedini gören Hero'da kendini boğazın buz gibi soğuk sularına atarak intihar eder (Demirdurak, 2013: 54).

Kız Kulesi ile ilgili bilinen son efsanede ise 8. yüzyıla damgasını vurmuş Emevi askeri olan Battal Gazi, beraberindeki kuvvetlerle birlikte kulenin civarında konuşlanmıştır. Panik yapan imparator, kızını ve kıymetli hazinelerini kulenin içinde gizli bir yere saklamıştır. Emrindeki askerler ile kuleyi basan Battal Gazi hem prensesi hem de hazineyi almış ve atıyla Üsküdar'dan yıldırım gibi geçerek uzaklaşmıştır. Meşhur "Atı alan Üsküdar'ı geçti” sözü de bu hikayeden ortaya çıkmıştır (Tonguç ve Tutuk, 2019: 278).

\section{Araştırmanın Amacı}

Galata Kulesi ve Kız Kulesi İstanbul'un iki önemli sembolüdür. Yerli turistlerin, bu iki kuleyi ziyaret etmesinde yüzyıllardır anlatılagelen efsanelerin etkisinin olup olmadığı araştırmanın amacını oluşturmaktadır. Ayrıca Galata Kulesi'ni ziyaret eden turistler ile Kız Kulesi'ni ziyaret eden turistlerin, bu iki kule arasındaki "efsanevi aşk" hakkında ne kadar bilgi sahibi olduğu incelenmektedir.

\section{YÖNTEM}

$\mathrm{Bu}$ araştırmada nitel araştırma yöntemi kullanılmıştır. Araştırmada nitel yöntem kullanılmasının sebebi araştırmanın amacına uygun olan verilerin nitel yöntemle elde edilebileceği düşüncesidir. Araştırmacı, araştırmanın niteliğine bağlı olarak anket yerine mülakat tekniğiyle veri toplamayı uygun görebilir (Coşkun vd., 2017: 99). Bu nedenle araştırmada veri toplama aracı olarak görüşme tekniği seçilmiştir. Görüşme tekniği, deneyimler, tutumlar, düşünceler, niyetler, yorumlar, zihinsel algılar ve tepkiler gibi gözlenemeyen süreçleri anlamamızı sağlamakla birlikte karşı tarafın sorulan sorulara rahat ve doğru bir şekilde cevap vermesini sağlamasından dolayı seçilmiştir (Yıldırım ve Şimşek, 2016).

Yarı yapılandırılmış görüşmede mülakatçı, kaba hatlarıyla bir yol haritasına sahiptir ancak, katılımcının ilgi ve bilgisine göre bu genel çerçeve içerisinde farklı sorular sorarak konunun değişik boyutlarını ortaya çıkarmaya çalışır (Coşkun vd., 2017: 101). Görüşme için hazırlanan soru formunun oluşturulmasında ise literatürden elde edilen bilgilerden yararlanılmıştır (Aktaş ve Batman, 2010; Ar ve Uğuz, 2015; Grimwood, Stinson ve King, 2019).

Araştırmanın evrenini Galata Kulesi ve Kız Kulesi'ni ziyaret eden yerli turistler oluşturmaktadır. Galata Kulesi ve Kız Kulesi İstanbul'un iki farkı yakasında konuşlanmıştır. Mekan dağılımındaki 
farklı konumlar ve turist sayısının çokluğundan dolayı bu araştırmada nitel araştırmalarda kullanılan amaçlı örnekleme yönteminden yararlanılmıştır. Amaçlı örneklemede; ana kütle içerisinden, gözle tahmin ederek, bilgi edinmek istenen özelliği temsil edebilecek birimleri ayırmaktır. Bu yöntemle örnek seçiminde birimlerin seçilme olasılıkları bilinmediği gibi bu birimlere dayanan istatistik ölçülerin hatalarının da hesaplanması mümkün değildir. Örnek az sayıda birimden oluşabilir. (Yazıcıoğlu ve Erdoğan, 2014: 82). Araştırmada yapılan görüşmelerin belli bir noktada tekrar etmesinden dolayı her iki turistik mekan içinde 12 'şer katılımcıyla 26.12.2019-10.02.2020 tarihleri arasında görüşülmüştür. Araştırmacılar tarafından, görüşme soruları bizzat sorulmuş ve cevaplar ses kayıt cihazı ile izin alınarak kayıt edilmiştir.

Son aşamada ise katılımcılarla yapılan görüşmelerin bulgularını analiz etmek için nitel araştırmaların analiz yöntemlerinden biri olan söylem analizinden faydalanılmıştır. Söylem analizi, bireylerin doğada ortaya çıkan belirli olaylar ya da davranışlar hakkında kendi kişisel gerçeklerini nasıl oluşturdukları üzerine yoğunlaşmaktadır. Karşılıklı konuşma özelliğini yansıtması nedeniyle, bir bakıma her nitel veri analizi, kısmen de olsa, bir söylem analizini yansıtmaktadır. Her türlü yazılı ve sözlü bilgi kaynaklarından elde edilen metinsel veri, söylem analizinin altyapısını oluşturmaktadır. Araştırmanın amacı doğrultusunda söylemin içinde yer alan uygun anlatım ya da söylemler inceleme altına alınarak kullanılan dil, dilin içeriği, yapısı, kullanım biçimi vb. ölçütler bazında bir çıkarımda bulunulmasına çalışılmaktadır (Kozak, 2018: 127).

\section{BULGULAR}

Aşağıda yer alan Tablo 1'de Galata ve Kız Kulesi'ni ziyaret eden katılımcıların demografik bulgularına yer verilmiştir.

Tablo 1. Galata ve Kız Kulesi'ni Ziyaret Eden Katılımclların Demografik Özellikleri

\begin{tabular}{|c|c|c|c|c|c|}
\hline \multirow{2}{*}{ DEĞIŞKEN } & & \multicolumn{2}{|c|}{ GALATA KULESİ } & \multicolumn{2}{|c|}{ KIZ KULESİ } \\
\hline & & $\mathbf{N}$ & $\%$ & $\mathbf{N}$ & $\%$ \\
\hline \multirow{2}{*}{ Cinsiyet } & Kadın & 5 & 41 & 4 & 33,5 \\
\hline & Erkek & 7 & 59 & 8 & 66,5 \\
\hline \multirow{4}{*}{ Yaş } & $20-29$ & 6 & 50 & 6 & 50 \\
\hline & $30-39$ & 4 & 33 & 2 & 16,6 \\
\hline & $40-49$ & 1 & 8,5 & 2 & 16,6 \\
\hline & $50-59$ & 1 & 8,5 & 2 & 16,6 \\
\hline \multirow{4}{*}{ Eğitim } & İlkokul & - & - & 2 & 16,6 \\
\hline & Lise & 1 & 9 & 1 & 8,3 \\
\hline & Lisans & 11 & 91 & 8 & 66,6 \\
\hline & Yüksek Lisans & - & - & 1 & 8,3 \\
\hline \multirow{11}{*}{ Meslek } & Diyetisyen & 1 & 8,4 & - & - \\
\hline & İşletmeci & 1 & 8,4 & - & - \\
\hline & Muhasebeci & 1 & 8,4 & - & - \\
\hline & Öğretmen & 2 & 16,4 & - & - \\
\hline & Öğrenci & 6 & 50 & 6 & 50 \\
\hline & Mühendis & 1 & 8,4 & - & - \\
\hline & Akademisyen & - & - & 1 & 8,3 \\
\hline & Bilgi İşlem Görevlisi & - & - & 1 & 8,3 \\
\hline & Esnaf & - & - & 1 & 8,3 \\
\hline & Ev Hanımı & - & - & 1 & 8,3 \\
\hline & Emekli & - & - & 2 & 16,6 \\
\hline
\end{tabular}


Tablo 1'de görüldügüü üzere Galata Kulesi'ni ziyaret eden turistler arasından seçilen katılımcilar, cinsiyet açısından incelendiğinde \%59'unun erkek, \%41'inin kadın olduğu tespit edilmiştir. Yaş bakımından incelendiğinde büyük bir çoğunluğun 20'li ve 30'lu yaş grubunda olduğu söylenebilir. Katılımcılar eğitim durumları açısından incelendiğinde 1 kişinin lise, kalan 11 kişinin ise lisans mezunu olduğu görülmektedir. Son olarak katılımcıların yarısının öğrenci, diğer yarısının ise farklı meslek gruplarından kişiler olduğu belirlenmiştir. Kız Kulesi'ni ziyaret eden turistler arasından seçilen katılımclar, cinsiyet açısından incelendiğinde ise \%66,5'inin erkek, \%33,5'inin kadın olduğu görülmektedir. Yaş bakımından incelendiğinde, Galata Kulesi'ndeki gibi büyük bir çoğunluğun 20'li ve 30'lu yaş grubunda olduğu tespit edilmiştir. Katılımcıların eğitim durumlarına bakıldığında 2 kişinin ilkokul, 1 kişinin lise, 8 kişinin lisans ve son olarak 1 kişinin de yüksek lisans mezunu olduğu görülmektedir.

Aşağıda yer alan Tablo 2' de katılımcıların Galata ve Kız Kulesi'ni ziyaret etme amacına yönelik bulgulara yer verilmiştir.

Tablo 2. Galata ve Kız Kulesi'ni Ziyaret Etme Amacına Yönelik Bulgular

\begin{tabular}{lc|c}
\hline Galata / Kız Kulesi'ni ziyaret etme & GALATA KULESİ & KIZ KULESİ \\
\cline { 2 - 3 } amacınız nedir? & Kişi Sayısı & Kişi Sayısı \\
\hline Arkadaşlarımla kaliteli vakit geçirmek & 5 & - \\
\hline Kültür & 4 & - \\
\hline Öğrenme (Merak) & 3 & - \\
\hline Boş vakitlerin değerlendirilmesi & - & 6 \\
\hline Tarih ve kültür amaçlı & - & 6 \\
\hline
\end{tabular}

Katılımcılara "Galata Kulesi'ni ziyaret etme amacınız nedir?" sorusu yöneltilmiştir. 5 katılımcı arkadaşlarıyla beraber kaliteli vakit geçirmek için Galata Kulesi'ni ziyaret ettiklerini, 4 katılımcı ise kültür odaklı geziler yapmanın ziyaretlerinin temel motivasyonu olduğunu ifade etmiştir. Son olarak 3 katılımcı ise Galata Kulesi'ni yeni şeyler öğrenme duygusuyla ziyaret etme isteği taşıdıklarını belirtmiştir. Elde edilen bulgular doğrultusunda Galata Kulesi'ni ziyaret eden katılımcıların bir kısmının arkadaşlarıyla kaliteli vakit geçirme isteğinde olduğu görülmektedir. Bu noktadan hareketle turistik mekanların aynı zamanda bir sosyalleşme aracı olarak da ziyaret edildiğini söylemek mümkündür.

Katılımcılara "Kız Kulesi'ni ziyaret etme amacınız nedir?" sorusu yöneltilmiştir. 6 katılımcı boş zamanlarını değerlendirme noktasında sembol bir mekan olan Kız Kulesi'nin çekici bir yönünün olduğunu belirtmiştir. Diğer 6 katılımcı ise Kız Kulesi'nin tarih içindeki sürecini merak ettiklerinden dolayı ziyarette bulunduklarını ifade etmişlerdir. Elde edilen bulgular doğrultusunda katılımcıların turistik mekanların sembolik anlamlarına önem verdiği görülmektedir. Aynı zamanda tarihe tanıklık etmiş bu mekanların katılımcılarda bir ilgi oluşturduğunu ve tarihsel açıdan güçlü bu mekanların turizme pozitif katkılar sunacağını söylemek mümkündür.

Aşağıda yer alan Tablo 3'te katılımcıların Galata ve Kız Kulesi'ni ziyaret etmeden önce bilgi toplaması ile ilgili bulgulara yer verilmiştir. Katılımcılara "Galata Kulesi'ni ziyarete gelmeden önce burayla ilgili araştırma yaptınız mı?" sorusu yöneltilmiştir. 5 katılımcı Galata Kulesi'nin tarihi, kim tarafından yapıldığı ve efsaneleri ile ilgili okumalar yaptığını, 7 katılımcı ise Galata Kulesi'ni ziyarete gelmeden önce herhangi bir araştırma yapmadığını ifade etmiştir. Buna rağmen İstanbul'un imajı açısından Galata Kulesi'ni etkileyici bir mekan olarak gördüklerini 
ifade etmişlerdir. Elde edilen bulgular doğrultusunda imaj yönüyle öne çıkan turistik mekanların ziyaretçiler açısından daha çekici olduğu söylenebilir.

Tablo 3. Galata ve Kız Kulesi'ni Ziyaret Etmeden Önce Bilgi Toplama ile İlgili Bulgular

\begin{tabular}{lc|c}
\hline Galata / Kız Kulesi'ni ziyarete gelmeden önce & GALATA KULESİ & KIZ KULESİ \\
\cline { 2 - 3 } burayla ilgili araştırma yaptınız mı? & Kişi Sayısı & Kişi Sayısı \\
\hline Araştırma yaptım & 5 & 6 \\
\hline Araştırma yapmadım & 7 & 6 \\
\hline
\end{tabular}

Katılımcılara "Kız Kulesi'ni ziyarete gelmeden önce burayla ilgili araştırma yaptınız mı?" sorusu yöneltilmiştir. Katılımcıların yarısı Kız Kulesi'nin geçmişten günümüze farklı formlarda kullanılmasıyla ilgili bilgiler topladıklarını belirtmişlerdir. Özellikle "Sepetteki zehirli yılan" efsanesinin kendilerini çok etkilediği için çeşitli araştırmalar yaparak Kız Kulesi'ni ziyarete geldiklerini belirtmişlerdir. Katılımcıların diğer yarısı ise Kız Kulesi'ni ziyarete gelmeden önce herhangi bir bilgi toplama çalışması yapmadıklarını ifade etmiştir. Kız Kulesi ziyaretlerini rekreasyon faaliyeti kapsamında değerlendirdikleri tespit edilmiştir. Elde edilen bulgular doğrultusunda katılımcıların "efsaneleri" olan turistik mekanlara ilgi duyduğu görülmektedir. $\mathrm{Bu}$ noktadan hareketle efsane ve söylence turizminin katılımcilarda araştırma duygusunu harekete geçirdiği çıkarımı yapılabilir.

Aşağıda yer alan Tablo 4'te katılımcıların Galata ve Kız Kulesi efsanelerinin bilinirliliğine ilişkin bulgulara yer verilmiştir.

Tablo 4. Galata ve Kız Kulesi Efsanelerinin Bilinirliliğine İlişkin Bulgular

\begin{tabular}{lc|c}
\hline Galata ve Kız Kulesi'nin efsaneleriyle ilgili & GALATA KULESİ & KIZ KULESİ \\
\cline { 2 - 3 } bir bilginiz var mı? & Kişi Sayısı & Kişi Sayısı \\
\hline Bilgim var & 7 & 8 \\
\hline Bilgim yok & 5 & 4 \\
\hline
\end{tabular}

Katılımcılara "Galata Kulesi'nin efsaneleriyle ilgili bir bilginiz var mı?" sorusu yöneltilmiştir. 7 katılımcı Galata Kulesi ile ilgili anlatılagelen efsanelerden haberi olduğunu belirtmiştir. Özellikle en eski Galata Kulesi efsanelerinden biri olan; “Çiftlerin Galata Kulesi'ne ilk kez birlikte çıarlarsa mutlaka evlenecekleri" hikayesinin katılımcılar tarafından bilinirliliği çok fazladır. Aynı zamanda Galata Kulesi ile Kız Kulesi arasındaki efsanevi aşk da katılımcıların etkileyici bulduğu bir diğer efsanedir. 5 katılımcı ise Galata Kulesi'nin efsaneleriyle ilgili herhangi bir bilgi sahibi olmadığını ifade etmiştir. Galata Kulesi'ne daha çok fotoğraf çektirmek ve panoramik manzarasının tadını çıkarmak için geldiklerini belirtmişlerdir.

Katılımcılara "Kız Kulesi'nin efsaneleriyle ilgili bir bilginiz var mı?" sorusu yöneltilmiştir. 8 katılımcı "Sepetteki zehirli yılan efsanesi" hakkında bilgi sahibi olduklarını belirtmişlerdir. Hatta bu efsanenin ziyaretlerini daha çekici kıldığını da ifade etmişlerdir. 4 katılımcının ise Kız Kulesi'nin efsaneleriyle ilgili herhangi bir bilgi sahibi olmadığı tespit edilmiştir. Kız Kulesi'ni daha çok fotoğraf çektirme ve manzaranın keyfine varma gibi bir bakış açısıyla gördükleri görüşü ağır basmaktadır. 
Elde edilen bulgular doğrultusunda Galata ve Kız Kulesi ile ilgili efsanelerin bazılarından, katılımcıların yarısından fazlasının bilgi sahibi olduğu görülmektedir. İstanbul gibi farklı imparatorluklara başkentlik etmiş kadim bir kentin soyut kültürel miras açısından taşıdığı önem büyüktür. Katılımcıların efsaneleri araştırdıktan sonra turistik mekanlara ziyaret gerçekleştirmeleri turizmin araştırmacı yönüyle örtüşmektedir.

Aşağıda yer alan Tablo 5'te Galata/Kız Kulesi ziyaretinin, Kız/Galata Kulesi' ni ziyaret etme isteği uyandırıp uyandırmadığına ilişkin bulgular bulunmaktadır.

Tablo 5. Galata/Kız Kulesi Ziyaretinin, Kız/Galata Kulesi'ni Ziyaret Etme İsteği Uyandırıp Uyandırmadığına İlişkin Bulgular

\begin{tabular}{|c|c|c|}
\hline Galata/K1z Kulesi'ni ziyaret ettikten sonra & GALATA KULESİ & KIZ KULESİ \\
\hline $\begin{array}{l}\text { Kiz/Galata Kulesi ni de ziyaret etme istegi } \\
\text { uyanıyor mu? }\end{array}$ & Kişi Sayısı & Kişi Sayısı \\
\hline Ziyaret etme isteği uyanıyor & 7 & 4 \\
\hline Ziyaret etme isteği uyanmıyor & 5 & 8 \\
\hline
\end{tabular}

Katılımcılara “Galata Kulesi' ni ziyaret ettikten sonra Kız Kulesi'ni de ziyaret etme isteği uyanıyor mu?" sorusu yöneltilmiştir. 7 katılımcı Galata Kulesi'ni ziyaret ettikten sonra Kız Kulesi'ni bu bağın bir tamamlayıcı unsuru olarak gördüğünü ifade etmişlerdir. Gerekçe olarak, iki kulenin İstanbul destinasyonu için bir marka kimliği taşıdığı belirtilmiştir. Aynı zamanda Galata ve Kız Kulesi'nin birbirlerine duydukları aşkını anlatan efsanenin, bu durumu daha ilgi çekici hale getirdiğini ifade etmektedirler. 5 katılımcı ise Galata Kulesi'ni ziyaret ettikten sonra Kız Kulesi'ni ziyaret etme isteğinin kendilerine bir anlam ifade etmediğini belirtmişlerdir. İki kuleyi birbirlerinden bağımsız gördüklerini belirtmişlerdir.

Katılımclara “Kız Kulesi'ni ziyaret ettikten sonra Galata Kulesi'ni de ziyaret etme isteği uyanıyor mu?" sorusu yöneltilmiştir. 4 katılımcı Kız Kulesi'ni ziyaret ettikten sonra Galata Kulesi'ni ziyaret ederek "sanki bir boşluğun" dolacağı duygusunu taşıdıklarını belirtmişlerdir. Bunun en büyük etkisi olarak ise iki kuleye atfedilen söylencelere konu olan aşkın olduğu ifade edilmiştir. 8 katılımcı ise Kız Kulesi'ni ziyaret etmenin Galata Kulesi'ni de ziyaret etme noktasında herhangi bir ilişki oluşturmadığını belirtmişlerdir.

Elde edilen bulgular doğrultusunda katılımcıların yarıya yakın bir kısmının Galata ya da Kız Kulesi'nden birini ziyaret ettiklerinde diğerini de ziyaret etme isteğinin kendilerinde oluştuğu görülmektedir. Özellikle Galata Kulesi ve Kız Kulesi ile ilgili efsanelere konu olan aşkın, katılımcıların ziyaret istediğinde bir çekicilik oluşturduğu söylenebilir.

Aşağıda yer alan Tablo 6'da Turistik destinasyonların efsanelere sahip olmasının turistik çekicilik oluşturup oluşturmadığına ilişkin bulgulara yer verişmiştir.

Katılımcılara "Bir turistik destinasyonun (mekanın) "efsaneleri" kapsamında tanınırlığı sizin o bölgeyi ziyaret etme noktasında isteğinizi arttırır mı?" sorusu yöneltilmiştir. Katılımcıların yarısından fazlası efsane ve söylencelerin insanlarda merak ve gizem uyandırdığını ve ilgi çekici olabileceğini belirtmişlerdir. 7 katılımcı ise efsane ve söylencelerin turistik mekanın ziyaretçi sayısını artırmada bir araç olabileceği fikrine olumsuz bakmaktadır. Elde edilen bulgular doğrultusunda Turizmi efsane ve söylencelerle zenginleştirip daha özgün bir form da sunmanın rekabetsel açıdan da belirleyici olacağı söylenebilir. 
Tablo 6. Turistik Destinasyonların Efsanelere Sahip Olmasının Turistik Çekicilik Oluşturup Oluşturmadığına İlişkin Bulgular

\begin{tabular}{lc}
\hline $\begin{array}{l}\text { Bir turistik destinasyonun (mekanın) "efsaneleri" kapsamında } \\
\text { tanınırlı̆̆ı sizin o bölgeyi ziyaret etme noktasında isteğinizi } \\
\text { arttırır mı? }\end{array}$ & Kişi Sayısı \\
\hline Evet Artırır & 17 \\
\hline Hayır Artırmaz & 7 \\
\hline
\end{tabular}

\section{TARTIŞMA ve SONUÇ}

İstanbul'un iki önemli simgesi olan; Galata Kulesi ve Kız Kulesi efsaneleri çalışmada ele alınmaktadır. Bu efsane ve söylencelerin; yerli turistlerin perspektifinden incelenmesiyle elde edilen bulgular, literatür ve yazar yorumları ile bu kısımda değerlendirilmektedir.

Katılımcların bir kısmının Galata Kulesi ve Kız Kulesi ziyaretlerindeki temel motivasyonlarının tarih, kültür ve yeni şeyler öğrenme duygusu olduğu görülmektedir. Turistik mekanların tarihsel süreç içerisinde biriktirdiği ilginç efsaneler katılımcılarda ziyaret edeceği turistik mekanla ilgili araştırma yapma isteği uyandırmaktadır. Bu sonuçlar İlban (2007), tarafından yapılan çalışmanın sonuçlarıyla benzerlik göstermektedir. İlban (2007), efsane ve söylencelerin; turistte merak uyandırdığı sonucuna ulaşmıştır.

Katılımcıların bir kısmının, Galata Kulesi ve Kız Kulesi ziyaretlerindeki temel motivasyonlarının arkadaşlarıyla vakit geçirme, panoramik manzarayı seyretme ve fotoğraf çektirme olduğu sonucuna ulaşılmıştır. Champbell ve Moyers (2009), tarafından yapılan çalışmada ise söylencelerin dört temel fonksiyonundan birinin mistik fonksiyon olduğu ifade edilmiştir. "Mistik fonksiyon: Evrenin ve insanoğlunun yerini fark etmek ve bu gizem karşısında huşu duymaktır. Gizem her yerde ve her şeyde ise, evren kutsal bir resim haline gelir" şeklinde belirtilmiştir.

Katılımcıların bir kısmının, Galata Kulesi ve Kız Kulesi ziyaretlerinden önce bu mekanlarla ilgili çeşitli araştırmalar yaparak bilgi topladıkları görülmüştür. Yerli turistlerin; Galata Kulesi ve Kız Kulesi'nin tarihi süreç içerisindeki rolü, kimler tarafından yapıldığı ve efsaneleri ile ilgili bir araştırma yapma ihtiyacı taşıdıkları sonucuna ulaşılmıştır. Bu sonuçlar Aktaş ve Batman (2010), tarafından yapılan çalışmanın sonuçları ile örtüşmektedir. Çalışmada yabancı turistlerin bölgeyi ziyarete gelme sebepleri arasında efsanelerin payı büyüktür ifadesine katılımcıların \%30,3'ü hiç katılmıyorum cevabını verirken yerli turistlerin bölgeyi ziyarete gelme sebepleri arasında efsanelerin katkısı büyüktür ifadesine verilen cevaplara bakıldığında \%36,1'i katılıyorum yanıtını vermişlerdir. $\mathrm{Bu}$ sonuçlar değerlendirildiğinde turist rehberlerinin perspektifinden; yerli turistlerin yabancı turistlere göre seyahat sebepleri arasında efsaneleri daha ön planda tuttukları belirtilmiştir. Ayn zamanda yerli turistlerin efsanelerle ilgili araştırma yaparak seyahatini ona göre planladığı sunucuna ulaşıldığı görülmektedir.

Katılımcıların bir kısmının, Galata Kulesi ve Kız Kulesi'ne ait efsaneleri ile ilgili bilgi sahibi olduğu görülmektedir. Galata Kulesi efsanesi olan “Çiftlerin Galata Kulesi'ne ilk kez birlikte çıkarlarsa mutlaka evlenecekleri" söylencesi ve Kız Kulesi efsanesi olan "sepetteki zehirli yılan söylencesi" nin katılımcılar tarafından bilindiği sonucuna ulaşılmıştır. Katılımcıların efsanelerle gittikleri turistik mekanı içselleştirdiği görülmektedir. Bu sonuçlar Simmons (2002), tarafından yapılan çalışmanın sonuçları ile uyuşmaktadır. Çalışmada, efsaneler ve söylencelerin turistin beklentilerine ve hislerine yönelik ise; turistin bu hatırayı ruhunun derinliklerinde hissettiği, 
duygusal bir deneyim yaşadığı için de kendisini şanslı görüp önemli hissedeceği sonucuna ulaşılmıştır.

Katılımcıların önemli bir kısmının, turistik mekanların efsane ve söylence kapsamındaki tanınırlı̆̆ını önemli bir ziyaret sebebi olarak gördüğü sonucuna ulaşılmıştır. Bu sonuçlar Bryon (2012), tarafından yapılan çalışmanın sonuçları ile uyuşmaktadır. Söylencelerin sadece duygulara hitap etmekle kalmayıp, aynı zamanda turizm bölgelerine yerel bir bakış açısı ekleme gücüne sahip oldukları belirtilmiştir. Turistik yerlerin sahip olduğu efsane ve söylencelerle, diğer rakiplere karşı oldukça güçlü bir satış gücüne sahip oldukları belirtilmiştir.

Katılımcların bir kısmının Galata Kulesi'ni ziyaret ettiğinde Kız Kulesi'ni ziyaret etme isteği; Kız Kulesi'ni ziyaret ettiğinde ise Galata Kulesi'ni ziyaret etme isteği olduğu tespit edilmiştir. Bu durumun sebebi ise Galata Kulesi ve Kız Kulesi arasında söylencelere konu olan aşkın olduğu sonucuna ulaşılmıştır. İstanbul'un simgesi sayılabilecek iki turistik mekan arasındaki söylencenin, katılımcıların perspektifinden etkileyici bir çekiciliğe sahip olduğu görüşü hakimdir. Bu iki somut mekan arasında, somut olmayan kültürel mirasa konu olan söylencenin özgün bir yanı olduğu sonucuna ulaşılmıştır. Aksungur ve Kastal (2007), tarafından yapılan çalışma ise turizmde markalaşma ile ilgili önemli tavsiyeler vermektedir. İnsanların ilgisini çekecek ilginç hikayelerin tanıtımda kullanılması çok etkin olmaktadır. Örneğin; Van Gogh'un kulağını kestiği yerin pazarlanması, resimlerini pazarlamaktan daha kolaydır. İstanbul gibi her bir turistik mekanında birçok efsane ve söylenceyi barındıran bir destinasyonun tanıtımlarında bu durumun kullanılmasının gerekliliği görülmektedir. Bu tema çerçevesinde çalışmaların yapılmamasının turizm sektörünün tanıtım planı kapsamında bir eksiklik olarak görüldüğü ifade edilebilir.

Sonuç olarak, İstanbul turistik açıdan sahip olduğu birçok çekiciliğin yanında somut olmayan kültürel miras açısından da çok zengin bir şehirdir. Bu değerler ne kadar anlatılırsa ve tanıtılırsa o kadar büyük geri dönüşler olacaktır. Sahip olunan ortak değerlerin kıymetini bilerek sahip çıkmak turizm sektöründeki bütün paydaşların en büyük görevleri arasındadır. İnsanlara, tarihten gelen sözlü geleneğin aktarılmasında turizm ile ilgili bütün paydaşların bütüncül bir koordinasyon içerisinde hareket etmesi gerekmektedir. Son dönemdeki turist profili yaşadığ deneyimin interaktif hale gelmesini isteyen bir topluluktur. Turistin seyahatine başlamadan önce turistik çekicilik merkezinde onu etkileyen; efsane ve söylencelerin ön plana çıkarılması başta İstanbul olmak üzere bütün Anadolu coğrafyasında, Türk turizm sektörüne artı bir güç katacaktır. Turist profillerinde meydana gelen değişiklikler, turistin beklentilerine daha fazla odaklanılması koşulunu ortaya koymaktadır. Turistin değişen ihtiyaçlarına göre bir politika belirlenmesi, ülkenin birçok turistik destinasyonunu çekim merkezi haline getirebilir.

Efsane ve söylenceler turistik mekanların popülerliğini artırmada önemli bir araç olarak kullanılabilir. Özellikle seyahat edilen yerlerin hafızada kalıcı bir şekilde yer edinmesinde söylencelerin önemli bir etkisinin olduğu görülmektedir. Bu konuda sadece turistlerin bireysel olarak konuya ilgi duymasının bir anlamı olmayacaktır. Turizm endüstrisi içerisindeki bütün paydaşların somut olmayan kültürel miraslarımıza sahip çıkarak, onları uluslararası bir değer haline getirecek çalışmalar içerisinde olmaları önerilmektedir.

Turistik mekanlara çekicilik katmak amacıyla "uydurma efsane" oluşturmanın da zararı olabilmektedir. Anlatılan efsanelerin herkes tarafından bilinirliği olan bir tema üzerinden kurgulanması gerekmektedir. Bu yaklaşımla hareket edilmesi destinasyonların tanıtımını pozitif yönde etkileyecektir.

Turizm endüstrisi konusunda karar verici aktörlerin en başında bulunan Kültür ve Turizm Bakanlığı'nın ulusal ve uluslararası kaynaklar aracılığıyla (Türkçe ve çeşitli yabancı dillerde tanıtıcı yayınlar: kitap, broşür, video, vb.) efsane ve söylencelerin tanıtımını yapmalıdır. Efsane 
ve söylencelerin unutulma riskine karşı, bu sözlü kültürlerin derlenerek bir referans kaynak haline getirilmesi önemlidir.

Galata Kulesi ve Kız Kulesi İstanbul'un önemli iki turistik mekanıdır. Turistlerin bu iki önemli kültür mirasını daha yakından tanıyabilmeleri için turistik mekanlarda özel etkinlikler planlanmalıdır. Yapılacak olan etkinliklerde turistlere; mekanların efsaneleri hikayeleştirilerek anlatılmalıdır. Efsanelerin bilinirliliğinin artırılması, İstanbul'un turist sayısının artmasını sağlayabilir.

Araştırmanın sonuçlarından hareketle; Galata Kulesi ve Kız Kulesi arasındaki efsane İstanbul'un tanıtımında bir pazarlama aracı olarak kullanılabilir. Aynı zamanda İstanbul'da Edirnekapı ve Üsküdar'daki Mihrimah Sultan Camii'leri arasında bulunan efsaneler de bu kapsamda değerlendirilebilir.

Turistik ürünün pazarlanmasında efsane ve söylencesi olan merkezlerin daha kolay pazarlandığ 1 bilinmektedir. Günümüz turist profili somut mimari eserler kadar, şehirlerin somut olmayan kültürel mirasını da merak etmektedir. Turizm endüstrisindeki kamu kurumları ve meslek örgütleri; ulusal tanıtımlar yaparken, bölgelerin yerel kimliğini de vurgulayarak pazarlama yapmanın farkındalığını oluşturmalıdır. İstanbul'u küresel ölçekte dünyaya anlatmaya çalışırken, İstanbul'un efsane ve söylencelerine ve yerel kimliğine vurgu yapmak destinasyonlar arasında rekabetsel bir avantaj yaratabilir. Ayrıca bu tür tanıtımların İstanbul'a gelmesi hedeflenen turist sayısını ve aylara göre dağılımını da arttıracağı ön görülebilir.

Araştırmada veriler görüşme tekniği ile elde edilmiştir. Gözlem ve anket gibi daha farklı tekniklerle veriler toplanabilir. Benzer ve karşılaştırmalı çalışmalar efsaneleriyle ön plana çıkmış diğer turistik tarihi mekanlarda gerçekleştirilebilir (Ayasofya, Topkapı Sarayı, Mihrimah Sultan Camii vb.) Bu araştırmada zaman önemli bir kısıtlılığı oluşturmaktadır. Zaman kısıtlılığından dolayı yabancı turistler araştırmaya dahil edilememiştir. Sonraki araştırmalarda yabancı turistlerin de örnekleme dahil edilmesi daha farklı sonuçların genellenebilmesi bakımından önem taşımaktadır.

\section{KAYNAKÇA}

Acarer, E. (2015). İstanbul Tarih, Mekân ve Strlar. İstanbul: İnkılap.

Aktaş, S., ve Batman, O. (2010). Efsanelerin Turistik Çekicilik Üzerine Etkileri: Profesyonel Turist Rehberlerine Yönelik Bir Araştırma. E-Journal of New World Sciences Academy Social Sciences, 5 (4), 367-395.

Ar, H., ve Uğuz, S. (2015). Somut Olmayan Kültürel Mirasın Korunmasında Turist Rehberlerinin Rollerine Yönelik Turist Algıları Üzerine Bir Araştırma, Uluslararası Sosyal Araştırmalar Dergisi, 8(41), 1406-1418.

Bassano, C., and Barile, S., and Piciocchi, P., and Spohrer, J., and Iandolo, F., and Less, R. (2019). Storytelling about places: Tourism marketing in the digital age. Cities, 87, 10-20.

Bryon, J. (2012). Tour Guides as Storytellers - From Selling to Sharing. Scandinavian Journal of Hospitality and Tourism, 12 (1), 27-43.

Campbell, J., and Moyers, B. (2009). Mitolojinin Gücü, Kutsal Kitaplardan Hollywood Filmlerine, Mitoloji ve Hikayeler. İstanbul: Mediacat, Kapital Medya Hizmetleri.

Coşkun, N. (2017). Van Efsanelerinin Turistik Çekime Dönüştürülmesi. Iwact 2017 Internatıonal West Asia Congress of Tournsm Research, 410-414. 
Coşkun, R., ve Altunışık, R., ve Yıldırım, E. (2017). Sosyal Bilimlerde Araştırma Yöntemleri Spss Uygulamalı. Sakarya: Sakarya Yayıncilık.

Demircan, S. (2011). İstanbul Tarihi ve Turistik Noktalar Rehberi. Ankara: Arkadaş.

Demirdurak, B. (2013). Türkiye Hakkında Çok Şey. İstanbul: Gita.

Dönmez, M., ve Güler, Ş. (2016), Transmedya Hikâyeciliği “Doritos Akademi” Örneği İncelemesi, Süleyman Demirel Üniversitesi Vizyoner Dergisi, 7 (16), 155-175.

Ersun, N., ve Arslan, K . (2015). Turizmde Destinasyon Seçimini Etkileyen Temel Unsurlar ve Pazarlama Stratejileri. Marmara Üniversitesi İktisadi ve İdari Bilimler Dergisi, 31 (2), 229-248

Gül, S. (2017). Mit ve Efsanelerin Amasya Turizmindeki Yeri. Uluslararası Amasya Sempozyumu, 1 (10), 1059-1078.

Güncel Türkçe Sözlük. (2020). Atasözleri ve Deyimleri Sözlüğü. https://sozluk.gov.tr/ [Erişim Tarihi: 26.01.2020].

Gündüz, Ş. (1998). Din ve İnanç Sözlüğ̈̈̈. Ankara: Vadi Yayınları.

Grimwood, B., and Stinson, M., and King, L. (2019). A decolonizing settler story. Annals of Tourism Research, 79,1-11.

https://www.bilgiw.xyz/bedri-rahmi-eyuboglu-istanbul-destani/ [Erişim Tarihi: 23.01.2020].

https://www.tarihiistanbul.com/tarihi-galata-bolgesi-ve-galata-kulesi/[Erişim Tarihi:26.01.2020].

https://docplayer.biz.tr/4065229-.html [Erişim Tarihi: 15.02.2020].

Hürel, H. (2015). İstanbul'u Geziyorum Gözlerim Açık. İstanbul: Kapı.

İlban, M. (2007). Destinasyon Pazarlamasında Marka İmajı ve Seyahat Acentalarında Bir Araştırma. Doktora Tezi. Ulusal Tez Merkezi (211536). Balıkesir Üniversitesi, Sosyal Bilimler Enstitüsü, Turizm İşletmeciliği Ana Bilim Dalı, Balıkesir.

Jeannotte, M. (2015). Story-telling about place: Engaging citizens in cultural mapping, City, Culture and Society, 7(1), 1-7.

Kara, M., ve Çiçek, B. (2015). Deneyimsel Pazarlama ve Satın Alma Karar Sürecine Etkisi: Termal Turizm Sektöründe Bir Uygulama. Gümüşhane Üniversitesi Sosyal Bilimler Elektronik Dergisi. 13, 177-200.

Kozak, M. (2018). Bilimsel Araştırma: Tasarım, Yazım ve Yayım Teknikleri. Ankara: Detay Yayıncılık.

McKercher, B., and Prideaux, B. (2014). Academic myths of tourism. Annals of Tourism Research, (46), 16-28.

Özünel, E. (2013). Yeni Miraslar ve Uluslararası Sözleşmelerde Sürdürülebilir Kalkınma Stratejileri. Milli Folklor, 25(100), 14-30.

Pine, J., and Gilmore, J.H. (1998). Welcome to the Experience Economy. Harvard Business Review, 76(4), 97-105.

Sakaoğlu, S. (1980). Anadolu-Türk Efsanelerinde Taş Kesilme Motifi ve Bu Efsanelerin Tip Kataloğu, Ankara: Kültür Bakanlığı Yayınları.

Sever, M. (2008). Toplumsal Bellek ve Geleneksel Eylem Bağlamında Bir Sözel Tarih Metnin Değerlendirilmesi. Milli Folklor, 20(77), 61-68.

Şahin, H. (2009). Dalyan ve Köyceğiz Çevresinde Gelenek, Turizm ve Folklorizm. Milli Folklor, 21 (82), 50-55. 
Sezer, İ. (2019). Mitolojik ve Efsanevi Unsurların Turistik Çekicilik Üzerine Etkilerinin Değerlendirilmesi: Giresun Adası Örneği. Turkish Studies- Social Sciences, 14 (5), 2463-2500.

Tonguç, S. ve Tutuk, Z. (2019). Kanatlarımda İstanbul. İstanbul: Alfa.

Türker, A., ve Çelik, İ. (2012). Somut Olmayan Kültürel Miras Unsurlarının Turistik Ürün Olarak Geliştirilmesine Yönelik Alternatif Öneriler. Yeni Fikir, 9,86-98.

Uslu, M. (2018). Yürüyerek İstanbul. İstanbul: Mona.

Uygur, S. M., Demirer, D. ve Hatırnaz, B. (2017). “Turizm Pazarlamasında Alternatif Bir Araç Olarak Hikâyelerin Kullanımı" Akademik Sosyal Araştırmalar Dergisi, 5(42), 34-42.

Yavuz, M. (1998). Ortak (Anonim) Halk Edebiyatı Türk Halk Düzyazısı-II, Eskişehir: T.C. Anadolu Üniversitesi Yayınları.

Yazıcıoğlu, Y., ve Erdoğan, S. (2014). Spss Uygulamalı Bilimsel Araştırma Yöntemleri. Ankara: Detay Yayincilık.

Yenipınar, U. (2018). Efsane ve Söylence Turizmi. Ş. Editör \& B. Editör, Turizmde Güncel Konu ve Eğilimler II 325-342. Ankara: Detay Yayıncilık.

Yıldırım, A., ve Şimşek, H. (2016). Sosyal Bilimlerde Nitel Araştırma Yöntemleri, Seçkin Yayıncılık, Ankara. 